\title{
Anencephaly: a retrospective analysis in Singapore. 1976 to 1980
}

\author{
K C TAN, S S RATNAM, S R KOTTEGODA, AND S M M KARIM \\ From the Department of Obstetrics and Gynaecology, National University of Singapore, \\ Kandang Kerbau Hospital for Women, Hampshire Road, Singapore 0821.
}

SUMMARY Records of 93 cases of anencephaly from three maternity hospitals in Singapore between 1976 and 1980 were analysed. The incidence was 0.54 per 1000 births. No significant correlation between anencephaly and local seasonal conditions could be found for Singapore.

Anencephaly is the commonest type of single monster among fetal malformations. The defect is the result of failure or primary arrest of closure of the cerebral end of the neural tube. This pathological basis was first suggested by von Recklinghausen and confirmed by Sternberg in his study of young human embryos.

The cause of anencephaly is still obscure. Renwick ${ }^{1}$ suggested the ingestion of blighted potatoes early in pregnancy as a cause, and Lowe et $a l^{2}$ implicated the level of calcium in the drinking water as the cause of anencephaly and spina bifida. However, both were found later to be interesting but unproven hypotheses. ${ }^{34}$

Nutritional factors have also been considered as a cause of neural tube defects. A possible link between folate deficiency and these defects in man was first suggested by Hibbard and Smithells, ${ }^{5}$ but other workers have failed to demonstrate this correlation. Smithells and co-workers ${ }^{6}$ suggested that antenatal multivitamin supplements might reduce the recurrence risk of anencephaly. Unfortunately, their study was based on a non-randomised sample and, furthermore, they were unable to pinpoint the lack of which vitamin was likely to have been responsible for the malformation.

There is a higher incidence of anencephalic pregnancies among European populations than among Asian populations (table 1). Elwood ${ }^{7}$ and Carter and Evans ${ }^{8}$ reviewed the incidence of anencephaly in the United Kingdom and found that it was higher in the western and northern areas. It was more frequent in the winter months, especially January and February.

Received for publication 26 September 1983. Accepted for publication 4 January 1984.
A 5 year review of anencephaly in the major maternity hospitals in Singapore was undertaken to see if there was a correlation between anencephaly and the seasonal conditions prevailing in the country.

\section{Materials and methods}

The present study analyses the anencephalic preg nancies recorded among 171773 consecutive deliv eries over a 5 year period (1.1.76 to 31.12 .80$)$ in? three major maternity hospitals, namely Alexandra

TABLE 1 Incidence of anencephaly.

\begin{tabular}{llll}
\hline Place & $\begin{array}{l}\text { Incidence } \\
(\text { per 1000) }\end{array}$ & Reference & Year \\
\hline Aberdeen, UK & $1 \cdot 60$ & 9 & 1958 \\
Belfast, UK & $3 \cdot 95$ & 7 & 1970 \\
Birmingham, UK & $2 \cdot 0$ & 10 & 1972 \\
Dublin, UK & $5 \cdot 10$ & 11 & 1957 \\
Liverpool, UK & $3 \cdot 10$ & 12 & 1968 \\
London, UK & $1 \cdot 41$ & 8 & 1973 \\
Paris, France & $0 \cdot 54$ & 13 & 1964 \\
Sweden & $1 \cdot 09$ & 14 & 1968 \\
Rhode Island, USA & $1 \cdot 94$ & 15 & 1953 \\
India & $4 \cdot 80$ & 16 & 1978 \\
Taipei, Taiwan & $1 \cdot 15$ & 17 & 1965 \\
Japan & $0 \cdot 60$ & 18 & 1958 \\
Thailand & $0 \cdot 21$ & 19 & 1979 \\
Singapore & 0.62 & 20 & 1959 \\
Singapore & $0 \cdot 21$ & 21 & 1964 \\
Singapore & $0 \cdot 25$ & 22 & 1970 \\
Singapore & 0.49 & 23 & 1978 \\
\hline
\end{tabular}

At the request of the editor, Dr Tan was asked about the nutritional status of the Singapore population, particularly with respect to vitamin deficiencies. Dr Tan replied as follows: "With reference to your question, I would like to point out that in Singapore multivitamin supplements are routinely provided by the health care institutes, including government maternity clinics and private practitioners, to all pregnant women throughout their antenatal period. Therefore, there is no evidence of vitamin deficiencies in these women during their pregnancies. So far, to my knowledge, no study in Singapore has been carried out to correlate the individual vitamin deficiency and the incidence of anencephaly". 
Hospital, Kandang Kerbau Hospital, and Toa Payoh Hospital, in Singapore. The births in these hospitals account for $84.9 \%$ of the total births of Singapore in the same period (table 2). Therefore, the results of this study may be taken to approximate closely to the situation in the whole country.

\section{Results}

\section{INCIDENCE}

A total of 93 cases of anencephalic pregnancy was recorded. The incidence was 0.54 per 1000 births or 1 in 1847 deliveries (table 3).

RA CE

The racial distribution of anencephalic pregnancy in Singapore was Chinese $72 \%$, Malays $14 \%$, and Indians $14 \%$ (table 4 ).

\section{MATERNAL AGE}

The age distribution of mothers who gave birth to anencephalic infants is shown in table 5. The incidence was highest in those between 25 and 29 years of age.

TABLE 2 Total birth rate in three maternity hospitals in Singapore, 1.1.76 to 31.12.80.

\begin{tabular}{llll}
\hline Year & \multicolumn{2}{l}{ No of deliveries } & $\begin{array}{l}\text { Percentage } \\
\text { Three hospitals/Singapore }\end{array}$ \\
\cline { 2 - 3 } & Three hospitals & Singapore & \\
\hline 1976 & 36782 & 42000 & $87 \cdot 6$ \\
1977 & 32762 & 38807 & $84 \cdot 4$ \\
1978 & 33475 & 39473 & $84 \cdot 8$ \\
1979 & 34592 & 40847 & $84 \cdot 7$ \\
1980 & 34162 & 41217 & $82 \cdot 9$ \\
Total & 171773 & 202344 & $84 \cdot 9$ \\
\hline
\end{tabular}

TABLE 3 Incidence of anencephaly in Singapore, 1.1.76 to 31.12 .80 .

\begin{tabular}{llll}
\hline Year & $\begin{array}{l}\text { Total No } \\
\text { of births }\end{array}$ & $\begin{array}{l}\text { No of } \\
\text { anencephaly }\end{array}$ & $\begin{array}{l}\text { Per 1000 } \\
\text { births }\end{array}$ \\
\hline 1976 & 36782 & 23 & 0.63 \\
1977 & 32762 & 15 & 0.46 \\
1978 & 33475 & 21 & 0.63 \\
1979 & 34592 & 15 & 0.43 \\
1980 & 34162 & 19 & 0.56 \\
Total & 171773 & 93 & 0.54 \\
\hline
\end{tabular}

TABLE 4 Racial distribution of anencephalic pregnancy i. Singapore.

\begin{tabular}{lcc}
\hline Ethnic group & No of cases & Percentage \\
\hline Chinese & 67 & 72 \\
Malay & 13 & 14 \\
Indian & 13 & 14 \\
Others & 0 & 0 \\
Total & 93 & 100 \\
\hline
\end{tabular}

TABLE 5 Maternal age distribution in anencephaly.

\begin{tabular}{lcc}
\hline Age $(y r)$ & No of cases & Percentage \\
\hline $15-19$ & 6 & $6 \cdot 4$ \\
$20-24$ & 19 & $20 \cdot 4$ \\
$25-29$ & 46 & $49 \cdot 5$ \\
$30-34$ & 16 & $17 \cdot 2$ \\
$35-39$ & 5 & $5 \cdot 4$ \\
$40-44$ & 1 & $1 \cdot 1$ \\
45 and over & - & $-100 \cdot 0$ \\
Total & 93 & 1 \\
\hline
\end{tabular}

PARITY

The distribution of parity is shown in table 6. It appeared to be highest in primigravidae.

SEX OF INFANTS

There were 54 male and 39 female anencephalic infants giving a sex ratio of $1 \cdot 38: 1$.

\section{CONDITION AND STATE}

OF DEVELOPMENT

Among the anencephalic deliveries, 50 were stillbirths and 43 were neonatal deaths. The ratio was $1 \cdot 16: 1 \cdot 0$.

\section{YEARLY INCIDENCE}

The distribution of anencephaly in each year was fairly consistent. The incidence in the three hospitals is shown in fig 1 .

\section{MEAN MONTHLY INCIDENCE}

The number of anencephalic pregnancies occurring in each month was quite consistent. However, the incidence was marginally higher in January and September, and lower in the month following, that is, in February and October (table 7, fig 2).

\section{MONTHLY OCCURRENCE}

The occurrence of anencephaly in individual months over the 5 year period is shown in fig 3 .

\section{Discussion}

The incidence of anencephalic pregnancy in Singapore recorded from 1976 to 1980 in this study was 0.54 per 1000 births. It is in the same range as that of previous reports. ${ }^{20-23}$

The distribution of anencephaly among the ethnic

TABLE 6 Parity distribution of anencephalic pregnancies.

\begin{tabular}{llc}
\hline Parity & No of cases & Percentage \\
\hline 1 & 38 & $40 \cdot 9$ \\
2 & 23 & $24 \cdot 7$ \\
3 & 20 & $21 \cdot 5$ \\
4 and over & 12 & 12.9 \\
Total & 93 & 100.0 \\
\hline
\end{tabular}


groups in the present study showed a higher incidence among the Indian population $(14 \%)$ and a lower incidence in Chinese $(72 \%)$. The general racial distribution in Singapore is Chinese $76.9 \%$, Malays $14.6 \%$, Indians $6 \cdot 4 \%$, and others $2.1 \%(1980$

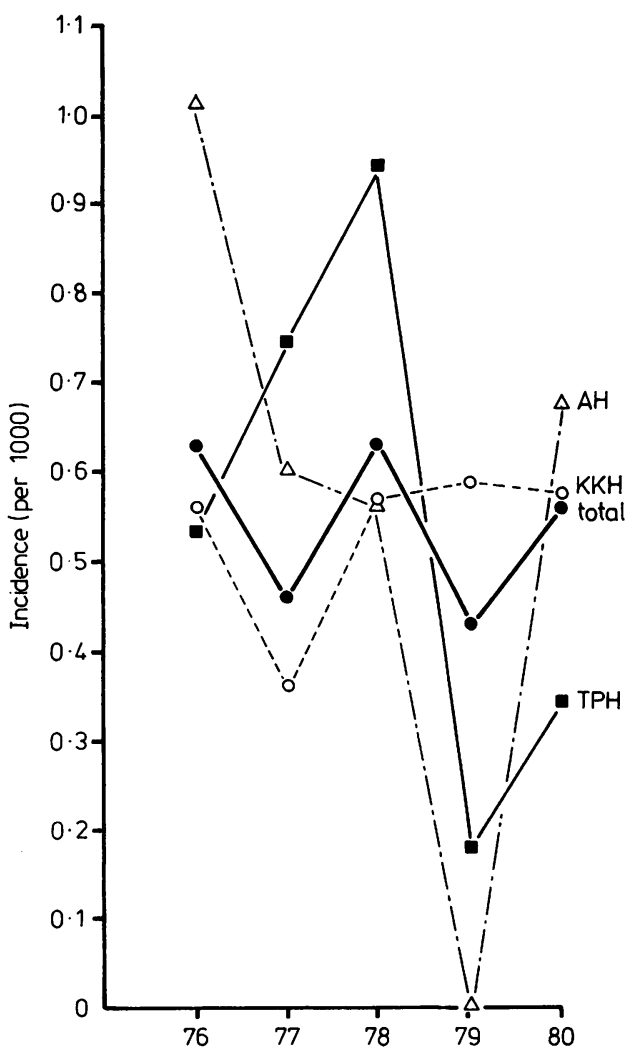

FIG 1 Yearly incidence of anencephalic pregnancies in Singapore.
TABLE 7 Mean monthly incidence of anencephalic pregnancy in Singapore, 1976 to 1980.

\begin{tabular}{lrl}
\hline Month & No of cases & Per 1000 births \\
\hline January & 15 & $1 \cdot 12$ \\
February & 3 & $0 \cdot 25$ \\
March & 4 & $0 \cdot 29$ \\
April & 6 & $0 \cdot 46$ \\
May & 10 & $0 \cdot 73$ \\
June & 8 & $0 \cdot 59$ \\
July & 12 & $0 \cdot 83$ \\
August & 4 & 0.90 \\
September & 14 & $0 \cdot 12$ \\
October & 2 & $0 \cdot 66$ \\
November & 10 & 0.34 \\
December & 5 & 0.54 \\
Total & 93 & \\
\hline
\end{tabular}

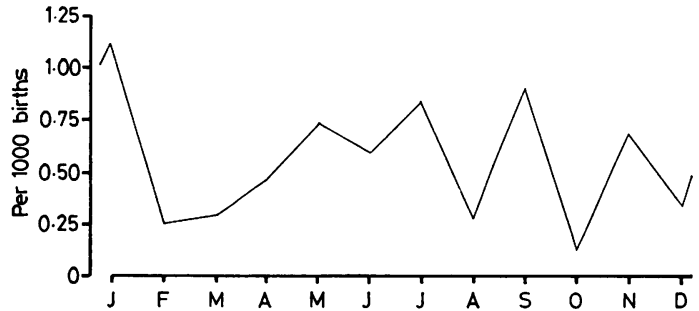

FIG 2 Mean monthly incidence of anencephalic pregnancies in Singapore, 1976 to 1980.

Population Census in Singapore). This finding suggests that a racial predisposition to the disease in Singapore might exist, and other reports have shown a higher incidence among European populations than among Asian populations (table 1). In India, there is a higher incidence of this condition in the population among Sikhs and this tendency is maintained even after their migration to the United Kingdom. ${ }^{16}$

Reports on the age distributions of the mothers of anencephalics compared to a control population have variously found an excess of younger women,, 920

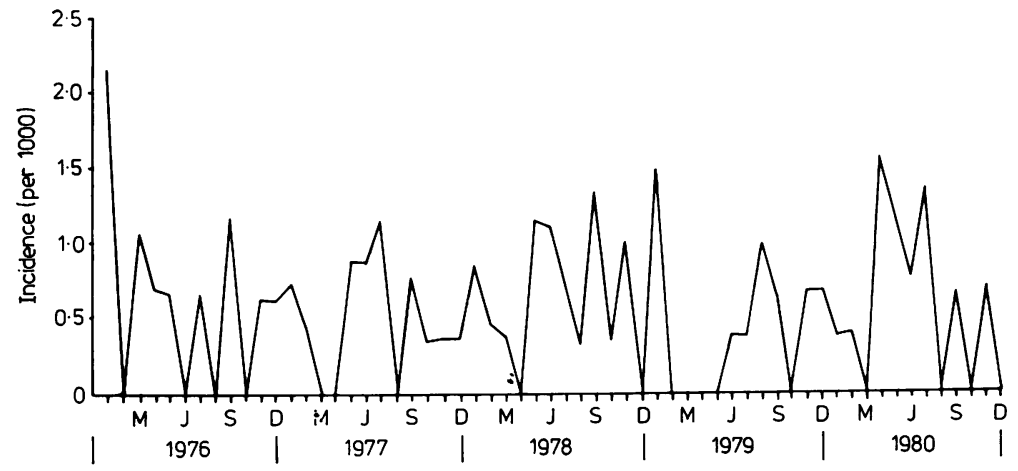

FIG 3 Monthly occurrence of anencephalic pregnancies in Singapore. 
an excess of older women, ${ }^{10}$ or both. ${ }^{11}{ }^{24}$ In contrast, studies in Oxford, ${ }^{25}$ in the Liverpool and Bootle areas, ${ }^{26}$ and in $\mathrm{Japan}^{27}$ did not detect any significant difference in maternal age distribution. In this study, there was a higher incidence of anencephaly in mothers aged between 25 and 29 years. However, no significant difference $\left(\chi^{2}=6 \cdot 004\right.$, $0 \cdot 50>p>0 \cdot 10)$ has been found when compared to the age specific fertility rates in Singapore (table 8). ${ }^{28}$

There was a higher incidence of anencephalic pregnancy among primigravidae $(40.9 \%)$. This happens to agree with the general fertility pattern in Singapore, as population growth in Singapore is well controlled by a family planning programme, and most parents stop at two children. Thus, there is no bias.

The present analysis showed a preponderance of male infants $(58 \cdot 1 \%)$, that is, a ratio of $1 \cdot 38: 1$ male to female anencephalic infants. In several reports it was noted that female infants predominated. ${ }^{29-31}$ On the other hand, in some other studies this has been found not to be so. ${ }^{1723} 32$ The results of this study are in agreement with the latter.

There have been conflicting reports over the years as to whether there is a seasonal variation in the incidence of anencephaly. Initial studies revealed a significant excess of winter births in Scotland, ${ }^{33}$ in Birmingham, ${ }^{10}$ in Belfast, ${ }^{7}$ in Greater London, ${ }^{8}$ and in Oxford. ${ }^{25}$ In contrast, no seasonal variation has been noted in the United States ${ }^{1534}$ or in Sweden. ${ }^{35}$ Furthermore, the incidence of this disease in certain temperate countries with marked seasonal changes, such as France and Japan, is strikingly similar to the findings in Singapore and Thailand (table 1). The climate in Singapore is rather hot and humid throughout the year. The mean monthly temperature does not vary by more than $1 \cdot 1^{\circ} \mathrm{C}$ from the mean annual value of $26.6^{\circ} \mathrm{C} .{ }^{36}$ The present study showed no increase in anencephalic deliveries in any particular month of the year in Singapore. Although the distribution was marginally higher in January and September, and lower in February and October, this finding was not statistically significant. It may be

TABLE 8 Age specific fertility rates in Singapore, 1976 to 1980 (per 1000 female population)*.

\begin{tabular}{lrrrrr}
\hline $\begin{array}{l}\text { All ethnic groups } \\
\text { Age }\end{array}$ & 1976 & 1977 & 1978 & 1979 & 1980 \\
\hline $15-19$ & $16 \cdot 2$ & $13 \cdot 4$ & $11 \cdot 8$ & $11 \cdot 4$ & $12 \cdot 2$ \\
$20-24$ & $107 \cdot 2$ & $90 \cdot 3$ & $86 \cdot 8$ & $85 \cdot 1$ & $79 \cdot 9$ \\
$25-29$ & $160 \cdot 2$ & $138 \cdot 9$ & $140 \cdot 9$ & $139 \cdot 3$ & $137 \cdot 3$ \\
$30-34$ & $95 \cdot 9$ & $85 \cdot 2$ & $86 \cdot 8$ & $88 \cdot 4$ & $84 \cdot 5$ \\
$35-39$ & $33 \cdot 8$ & $28 \cdot 7$ & $26 \cdot 7$ & $27 \cdot 5$ & $27 \cdot 2$ \\
$40-44$ & $8 \cdot 1$ & $6 \cdot 9$ & $5 \cdot 3$ & $5 \cdot 5$ & $5 \cdot 7$ \\
\hline
\end{tabular}

*Data cited from Fifteenth Annual Report, Singapore Family Planning and Population Board, 1980. that the number of cases in this study is insufficient to detect seasonal variation.

The authors wish to express their gratitude to the Medical Directors of the Alexandra Hospital, Kandang Kerbau Hospital, and Toa Payoh Hospital for permission to review case records of the hospitals. Our thanks are also due to Miss Julie Tan for secretarial assistance.

\section{References}

1 Renwick JH. Spina bifida, anencephaly and potato blight. Lancet 1972 ;ii:967.

2 Lowe CR, Roberts CJ, Lloyd S. Malformations of central nervous system and softness of local water supplies. $\mathrm{Br}$ Med $J$ 1971;ii:357-61.

3 Clarke CA, McKendrick OM, Sheppard PM. Spina bifida and potatoes. $\mathrm{Br}$ Med J 1973 ;iii:251-4.

${ }^{4}$ Leck I. Paediatric aspects of epidemiology-the frequency of disorders of early life. In: Davis JA, Dobbing J, eds. Scientific foundation of paediatrics. Philadelphia: Saunders, 1974:740-1.

5 Hibbard ED, Smithells RM. Folic acid metabolism and human embryopathy. Lancet 1965 ;i:1254-6.

6 Smithells RM, Sheppard S, Schorah CJ, et al. Possible prevention of neural tube defects by periconceptional vitamin supplementation. Lancet $1980 ; \mathbf{i}: 339-40$.

7 Elwood JH. Anencephalus in Belfast: incidence and secular and seasonal variation, 1955-1966. Br J Prev Soc Med 1970;24:78-88.

${ }^{8}$ Carter CO, Evans K. Spina bifida and anencephalus in Greater London. J Med Genet 1973;10:209-34.

9 Anderson WJR, Baird D, Thomson AM. Epidemiology of stillbirths and infant deaths due to congenital malformation. Lancet 1958 ; : 1304-6.

10 Leck I, Record RG, McKeown T, Edwards JH. The incidence of malformations in Birmingham, England, 1950-1959. Teratology 1972;1:263-80.

11 Coffey VP, Jessop WJEA. A study of 137 cases of anencephaly. Br J Prev Soc Med 1957;11:174-80.

12 Smithells RW. Incidence of congenital abnormalities in Liverpool, 1960-64. Br J Prev Soc Med 1968;22:36-7.

13 Frézal J, Kelley J, Guillemot ML, Lamy M. Anencephaly in France. Am J Hum Genet 1964;16:336-50.

14 Kallen B, Winberg J. Anencephaly in Sweden. J Pediatr $1968 ; 41: 765-8$.

15 McMahon B, Pugh TF, Ingalls TH. Anencephalus, spina bifida and hydrocephalus incidence related to sex, race and season of birth and incidence of siblings. $\mathrm{Br} J$ Prev Soc Med 1953;7:211-9.

16 Verma IC. High frequency of neural tube defects in North India. Lancet $1978 ; \mathrm{i}: 879-80$.

17 Wei PY, Chen YP. Congenital malformations, especially anencephalus, in Taiwan. Am J Obstet Gynecol 1965;91: $870-6$.

18 Neel JV. A study of major congenital defects in Japanese infants. Am J Hum Genet 1958;10:398-445.

19 Snidvongs W. Stillbirths - five years' experience at Chulalongkorn Hospital. In: Karim SMM, Tan KL, eds. Problems in perinatology. Proceeding of 1st Asia Oceania Congress of Perinatology, Singapore, 1979. Lancaster, London: MTP Press, 1979:188-92.

20 Searle AG. The incidence of anencephaly in a polytypic population. Ann Hum Genet 1959;23:279-88.

21 Wong HB. Congenital malformations in Singapore. Bull $K$ K Hosp 1964;2:1-6. 
22 Vengadasalam D. Anencephaly: a study of 29 cases. Proceedings of the Obstetrical and Gynaecological Society of Singapore 1970;1:20-3.

23 Woon KY. Anencephaly in Singapore. J Singapore Pediatr Soc 1978;20:177-82.

24 Carter CO. Spina bifida and anencephaly: a problem in genetic-environmental interaction. J Biosoc Sci 1969; 1:71-83.

25 Fedrick J. Anencephalus in the Oxford record linkage study area. Dev Med Child Neurol 1976;18:643-56.

26 Owens JR, McAllister E, Harris F, West L. 19-year incidence of neural tube defects in area under constant surveillance. Lancet 1981 ;ii:1032-5.

27 Imaizumi Y. Anencephaly in Japan: paternal age, maternal age and birth order. Ann Hum Genet 1979;42: 445-55.

28 Singapore Family Planning and Population Board. Fifteenth Annual Report, 1980.

29 Potter EL. Pathology of the fetus and newborn. Chicago: Year Book Medical Publishers, 1962.

30 Knox EG. Twins and neural tube defect. Br J Prev Soc Med $1974 ; 28: 73-80$.
31 James WH. The sex ratios of anencephalics born to anencephalic-prone women. Dev Med Child Neurol 1980; 22:618-22.

32 Jones WR. Anencephaly: a 23-year survey in a Sydney hospital. Med J Aust 1967;1:104-6.

33 Edwards JH. Congenital malformations of the central nervous system in Scotland. Br J Prev Soc Med 1958;12: 115-30.

34 Dalen P. Season of birth. Amsterdam: North-Holland, 1975.

35 Sandahl B. Seasonal incidence of some congenital malformations in the central nervous system in Sweden, 1965-1972. Acta Paediatr Scand 1977;66:65-72.

36 Meteorological Service, Singapore. Summary of observations, 1979:3.

Correspondence and requests for reprints to Dr K C Tan, 2 Marine Vista No 19-73, Singapore 1544, Republic of Singapore. 